\title{
Filarial dance sign in breast lump
}

\author{
Tulika Singh, Gurpreet Sandhu, ${ }^{\ominus}$ Veenu Singla
}

Radiodiagnosis and Imaging, Post Graduate Institute of Medical Education and Research, Chandigarh, Punjab, India

\section{Correspondence to}

Dr Gurpreet Sandhu, gurpreetsandhu1529@gmail. com

Accepted 26 March 2019

\section{DESCRIPTION}

A 35 -year-old woman presented with complaints of lump in her left breast from 1 year. Her mammography showed an oval-shaped isodense lesion in the upper outer quadrant of the left breast (figure 1) and the impression of breast imaging reporting and data sytem(BI-RADS) 2 was made. The patient presented to our hospital with a breast lump gradually increasing in size for the last few months. On examination, a small cystic swelling was palpable in the outer quadrant of the left breast. Ultrasonography showed few cysts in the upper quadrant of the left breast, the largest measuring $\sim 1.3 \times 0.7 \mathrm{~cm}$ at 1 o'clock position $\sim 3 \mathrm{~cm}$ from the nippleareola complex (figure 2). There were few dilated lymphatic channels seen adjacent to it. There were multiple curvilinear echoes seen within the cysts showing vigorous twirling movement giving typical filarial dance sign (video 1), thus confirming the diagnosis of breast filariasis. The patient's peripheral blood film for microfilaria was negative.

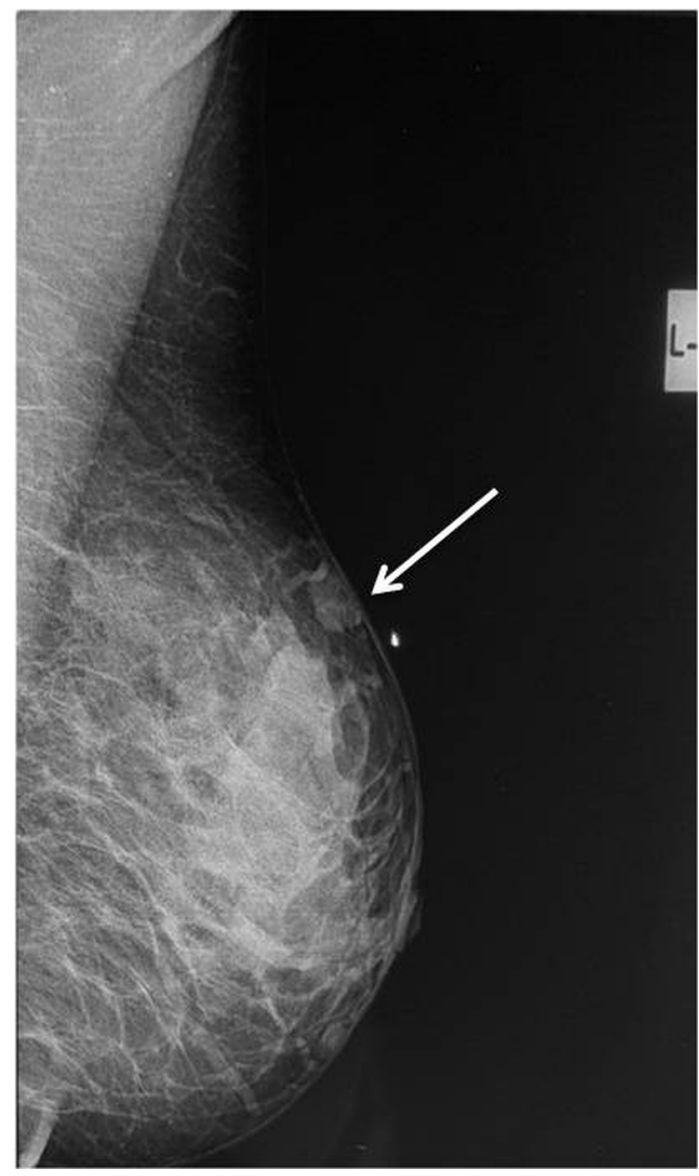

Figure 1 Mammography (mediolateral oblique [MLO] view, arrow) showing an oval-shaped isodense lesion in the upper outer quadrant of the left breast.

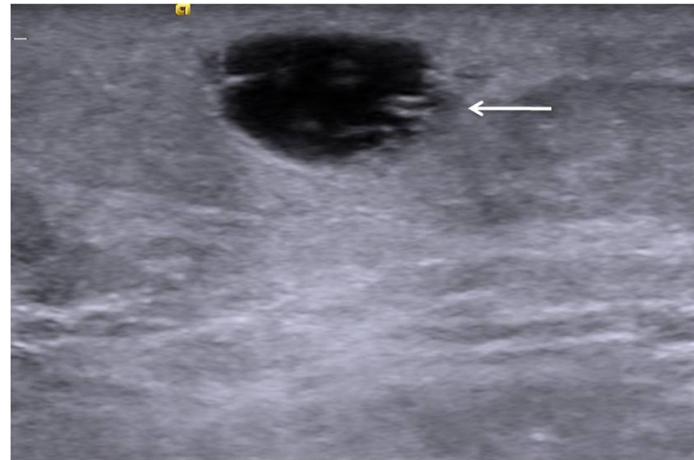

Figure 2 Ultrasonography (arrow) shows a cyst with few linear echogenic foci in the upper outer quadrant of the left breast.

However, in view of diagnostic appearance on imaging, she was started on treatment with Diethylcarbamazine in a dose of $6 \mathrm{mg} / \mathrm{kg} /$ day for 3 weeks. With treatment, there was a reduction in the size of cystic lesion in the breast with the absence of filarial dance sign on ultrasound examination.

In endemic areas, filariasis should be kept in the differential diagnosis of breast lump with imaging being diagnostic for its detection in most of the cases.

Lymphatic filariasis is seen generally in tropical countries with $90 \%$ of cases caused by Wuchereria bancrofti. ${ }^{1}$ The parasites commonly affect the lymphatic system involving the lower limbs, spermatic cord, epididymis and retroperitoneum. The breast is a rare extranodal site for the occurrence of tissue disease. In the breast, the larvae cause lymphangitis, fibrosis along with lymphatic obstruction and generally present as a small painless nodule in outer quadrant of the breast unilaterally. Other associated findings such as erythema of skin, peau de orange, fever or axillary lymphadenopathy

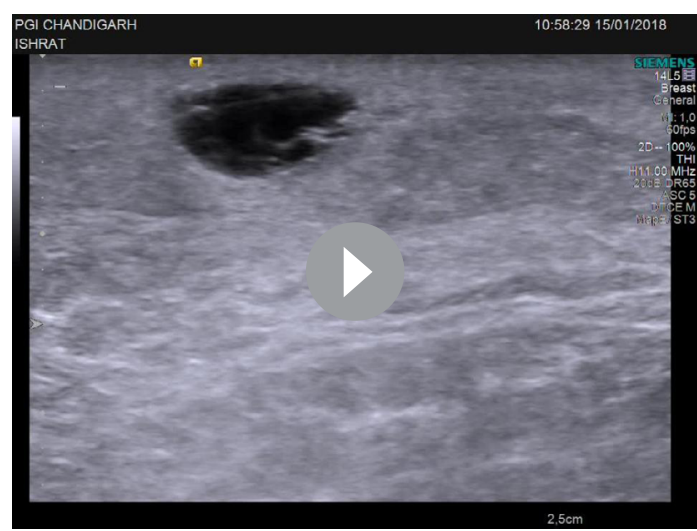

Video 1 Ultrasonography depicting multiple curvilinear echoes within the cyst showing vigorous twirling movement giving typical filarial dance sign. 


\section{Patient's perspective}

Breast lesions are generally thought to be tumour, but rarely, infection can also cause lump as was known after ultrasound detection in my case.

\section{Learning points}

- In endemic areas, filariasis is a differential diagnosis for breast lump.

- Ultrasound is a non-invasive modality for diagnosis of breast filariasis.

- Breast filariasis shows classical 'filarial dance sign' on ultrasound.

can be seen. ${ }^{2}$ Ultrasound is the diagnostic modality of choice with the classical 'filarial dance sign'. ${ }^{4}$ Microfilariae levels in blood examination can be low so a haemtological workup can be negative. Fine-needle aspiration cytology is an invasive technique for diagnosis of filariasis.

Contributors GS: Data acquisition, preparation of manuscript TS: study concept and revision of manuscript VS: Clinical care of the patient, revision of manuscript.

Funding The authors have not declared a specific grant for this research from any funding agency in the public, commercial or not-for-profit sectors.

Competing interests None declared.

Patient consent for publication Obtained.

Provenance and peer review Not commissioned; externally peer reviewed.

\section{REFERENCES}

1 Kapila K, Verma K. Diagnosis of parasites in fine needle breast aspirates. Acta Cytol 1996;40:653-6.

2 Sahai K, Kapila K, Verma K. Parasites in fine needle breast aspirates-assessment of host tissue response. Postgrad Med J 2002;78:165-7.

3 Amaral F, Dreyer G, Figueredo-Silva J, et al. Live adult worms detected by ultrasonography in human Bancroftian filariasis. Am J Trop Med Hyg 1994;50:753-7.

4 Sherwani P, Singhal S, Kumar N, et al. Breast filariasis diagnosed by real time sonographic imaging: A case report. Iran J Radiol 2016;13:17991.

Copyright 2019 BMJ Publishing Group. All rights reserved. For permission to reuse any of this content visit

https://www.bmj.com/company/products-services/rights-and-licensing/permissions/

BMJ Case Report Fellows may re-use this article for personal use and teaching without any further permission.

Become a Fellow of BMJ Case Reports today and you can:

- Submit as many cases as you like

- Enjoy fast sympathetic peer review and rapid publication of accepted articles

- Access all the published articles

- Re-use any of the published material for personal use and teaching without further permission

For information on Institutional Fellowships contact consortiasales@bmjgroup.com

Visit casereports.bmj.com for more articles like this and to become a Fellow 